\title{
Pakistan's energy scenario: a forecast of commercial energy consumption and supply from different sources through 2030
}

\author{
Abdul Rehman* and Zhang Deyuan
}

\begin{abstract}
Background: The energy sector in Pakistan is facing several challenges resulting from insufficient production. The major objective of this study is to identify and forecast commercial energy consumption and supply from different sources, including oil and petroleum, gas, electricity, and coal sources.

Methods: A forecasting method was utilized for investigating the future commercial energy consumption and supply from different sources.

Results: Forecasting results in the study reveal that the energy sector of Pakistan needs further attention to improve this sector, including the initiation of new policies and funding schemes to fulfill the country's demand.

Conclusion: Therefore, this study suggests that the government of Pakistan pay further attention to improving commercial energy consumption and supply from different sources to solve the energy crisis in the country.
\end{abstract}

Keywords: Energy consumption, Oil, Gas, Electricity, Agriculture and coal

\section{Background}

The energy sector of Pakistan is in crisis as a result of insufficient energy production to meet increased demand over the last decades. The major causes include debt recycling, financial conditions, and energy supplies. Natural gas and oil are the most dominant energy sources, with more than $80 \%$ of energy supply companies dependent on natural gas and oil. Low and cheap energy production from hydro electrical and coal resources are the main constraints that result in energy shortages and inadequate electricity production [1].

The demand for energy in Pakistan has increased due to the high population growth rate, which is estimated at about 3\% per year. The use of coal, natural gas, oil, and liquefied petroleum gas has grown to accommodate the surging demands in the country's energy sector. According to the Pakistan Economic Survey, consumption in the energy sector was 38.8 MTOE (million tonnes of oil equivalent) [2], which increased to 70.5 MTOE in 2016 [3, 4].

The energy sector plays a vital and important role in the development and economic growth of any country.

\footnotetext{
* Correspondence: abdlrehman@ahu.edu.cn

Research Center of Agricultural-Rural-Peasants, Anhui University, Hefei, China
}

Electricity - as a highly versatile form of energy-stimulates economic performance and plays an important role in the development of every sector of the economy. Over the past few decades, inadequate energy policy and energy production have plunged several countries into a severe power crisis, leading to poor economic performance $[5,6]$.

Over the past few decades, the failures of Pakistan's energy policy have plunged the country into a severe power crisis and have led to poor economic performance. Like other advanced countries $[7,8]$, the demand for electricity in Pakistan is partly determined by issues such as rapid population growth, economic expansion, and electricity prices. However, Pakistan's peculiar problems and its short-term power crisis arise from stealing, abuse, and over-utilization of electricity in homes and manufacturing as well as corruption, exaggerated, unreasonable or low institutional losses, mismanagement, and political arguments over large energy projects [9].

Multiple research studies have demonstrated that the energy sector is facing challenges globally in relation to sustainability, economics, and the environment. A range of models has been used to forecast and predict energy 
consumption and production. The major aim of this study is to forecast energy consumption from different sources including oil and petroleum, gas, electricity, and coal.

\section{Data sources and methodology \\ Data}

In this study, time series data was used to forecast the levels of future energy consumption of oil, gas, electricity, and coal. The data was collected from the Economic Survey of Pakistan and the Ministry of Petroleum and Natural Resources and Hydrocarbon Development Institute of Pakistan (HDIP).

\section{Methods}

To forecast future energy consumption of oil, gas, electricity, and coal, the following equation was used for forecasting $a+b x$, where

$$
a=\bar{y}-b \bar{x}
$$

and

$$
b=\frac{\sum(x-\bar{x})(y-\bar{y})}{\sum(x-\bar{x})^{2}}
$$

In this equation, the variables $x$ and $y$ represent the sample means average (known_x's) and average (known $\_$'s).

\section{Results and discussion}

The demand for energy has grown rapidly with the increase in usage and supply. The extent to which the economy is compromised by price increases depends on the proportion of oil as a share of national income, the ability of end users to reduce their oil consumption, and the degree of dependence on imported oil [10].

Figure 1 presents an overview of published data with regard to energy consumption of oil and petroleum in the household, industry, agriculture, transport, power, and other government sectors as well as the projected consumption to 2030 in tonnes.

Natural gas is the dominant fuel in Pakistan, accounting for about $47 \%$ of the major energy demand in 2012. Since 2000, the main energy sources in Pakistan are natural gas and oil, accounting for $50 \%$ and $29 \%$ of total energy consumption, respectively [11]. The annual consumption of natural gas, as one of the primary fossil fuels, has grown by $2.5 \%$. The annual production of natural gas comprised $23.9 \%$ of the global demand for energy in 2012 [12], and this percentage is predicted to grow to $50 \%$ by 2020 [13]. Figure 2 illustrates the levels of consumption of natural gas energy in different sectors from 2000 and includes the projected consumption until 2030. The figure shows consumption in the household, commercial, cement, power, fertilizer, and industrial sector.

Electricity consumption in Pakistan accounts for about $40 \%$ of global greenhouse gas (GHG) emissions. In 2013, $67.2 \%$ of the world's electricity production came from fossil fuel power plants, making them key players in the development of GHG mitigation and strategies for the energy and power production sectors [14, 15]. Power supply plays a vital role in achieving sustainability and economic prosperity in any country. In Pakistan, a developing nation with a population of over 200 million people, the demand for electricity is increasing exponentially, due to an increased demand in both the household and manufacturing sectors. Figure 3 not only shows the

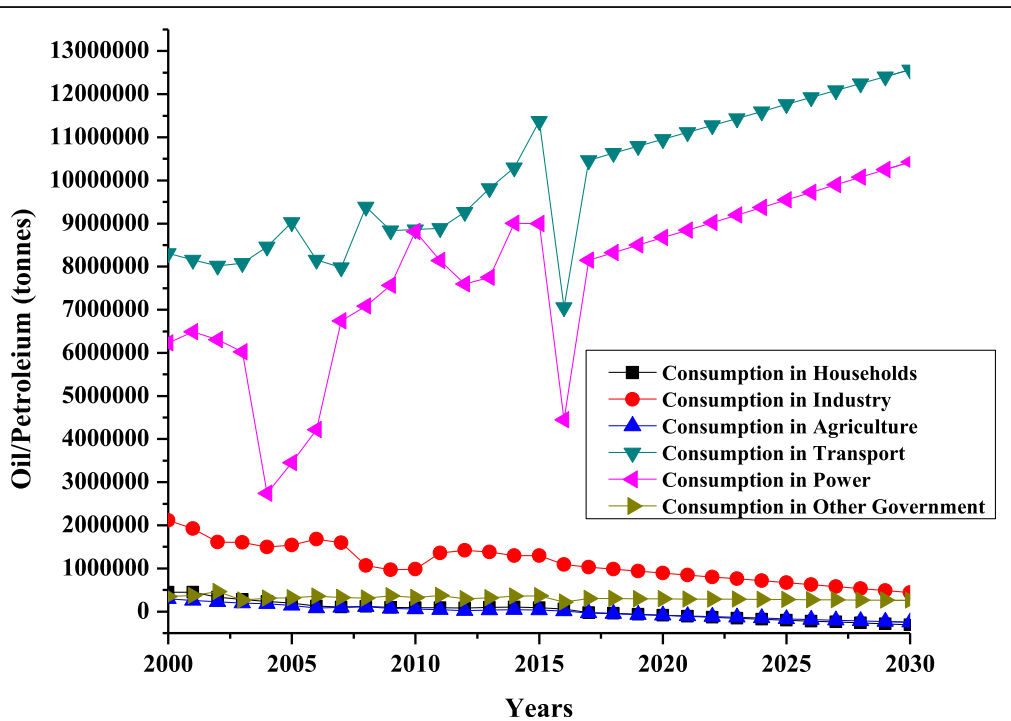

Fig. 1 Forecasted oil and petroleum energy consumption in households, industry, agriculture, transport, power, and other government sectors from 2000 to 2030 (Authors' computations) 


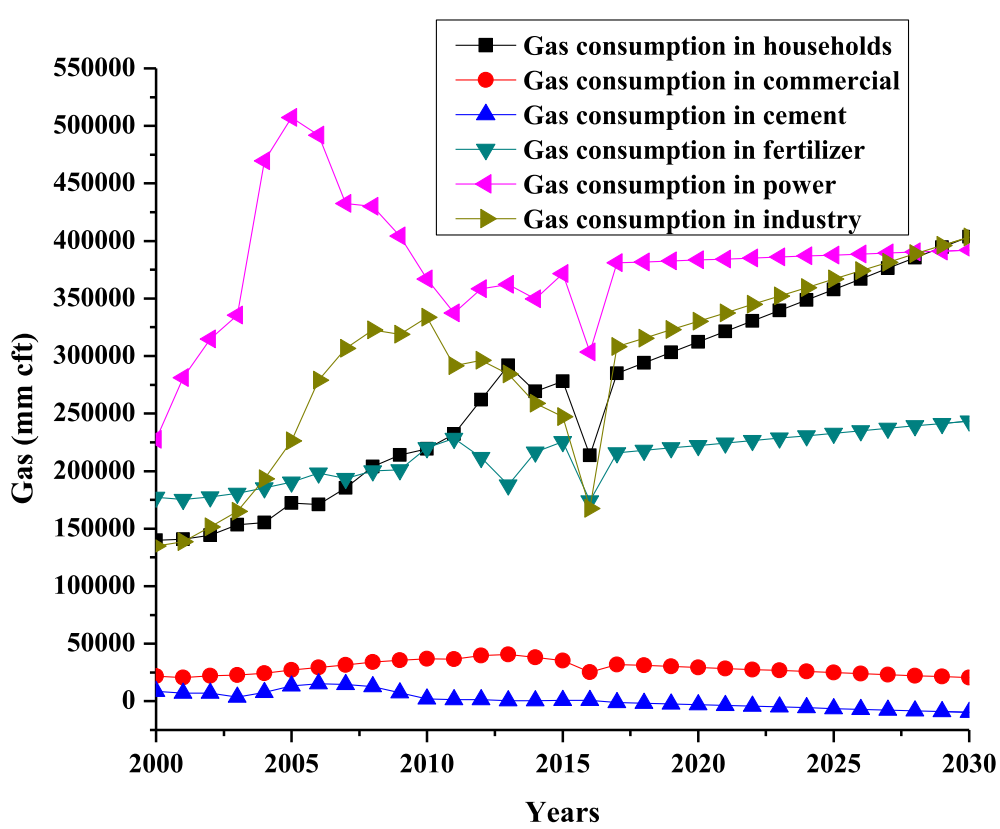

Fig. 2 Forecasted gas energy consumption in the households, industry, agriculture, transport, power, and industry from 2000 to 2030 (Authors' computations)

known electricity consumption in different sectors from 2000 but also gives projections to 2030 including electricity use for traction, households, commerce, industry, agriculture, street lights, and other governmental fields.

Hower et al. [16] determined that the demand for energy in Pakistan is growing rapidly as the GDP growth rate increases. Coal is a major resource for generating electricity and currently supplies $41 \%$ of global electricity demand. Coal accounts for $40 \%$ of the total global anthropogenic emissions of carbon dioxide, with about $70 \%$ stemming from the global electricity sector. For the production of heat and electricity, coal is considered as an important fuel,

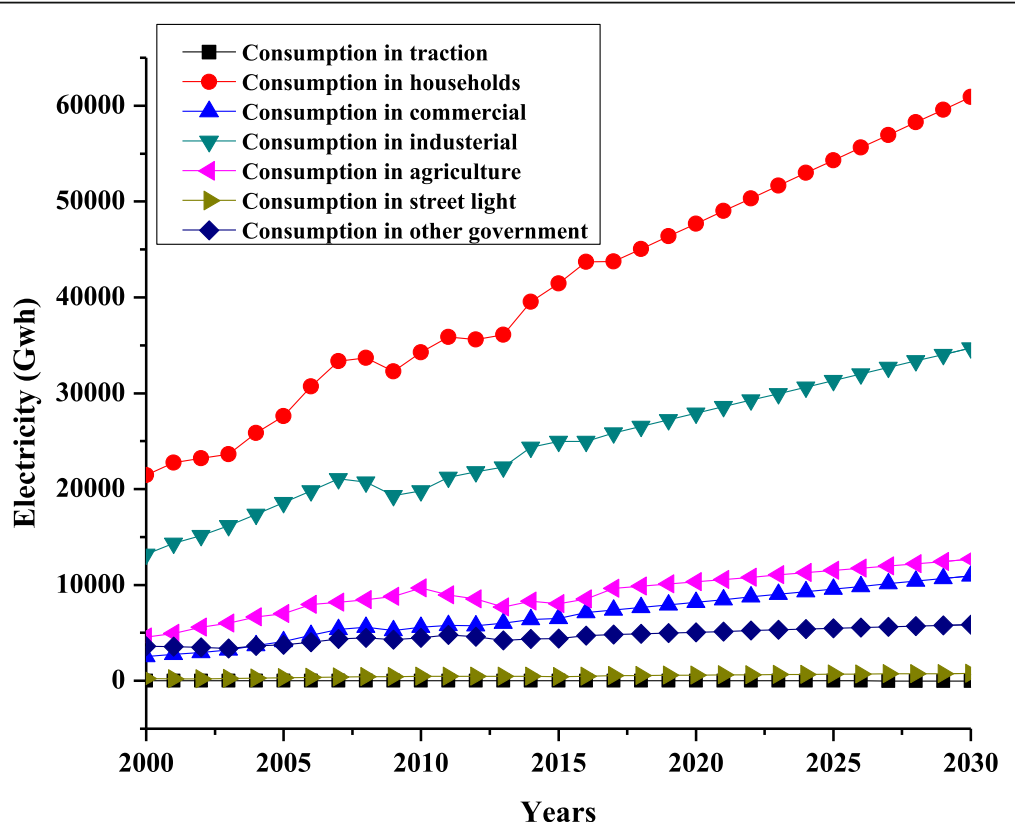

Fig. 3 Forecasted electricity energy consumption in traction, households, commercial, industrial, agriculture, street light, and other government from 2000 to 2030 (Authors' computations) 


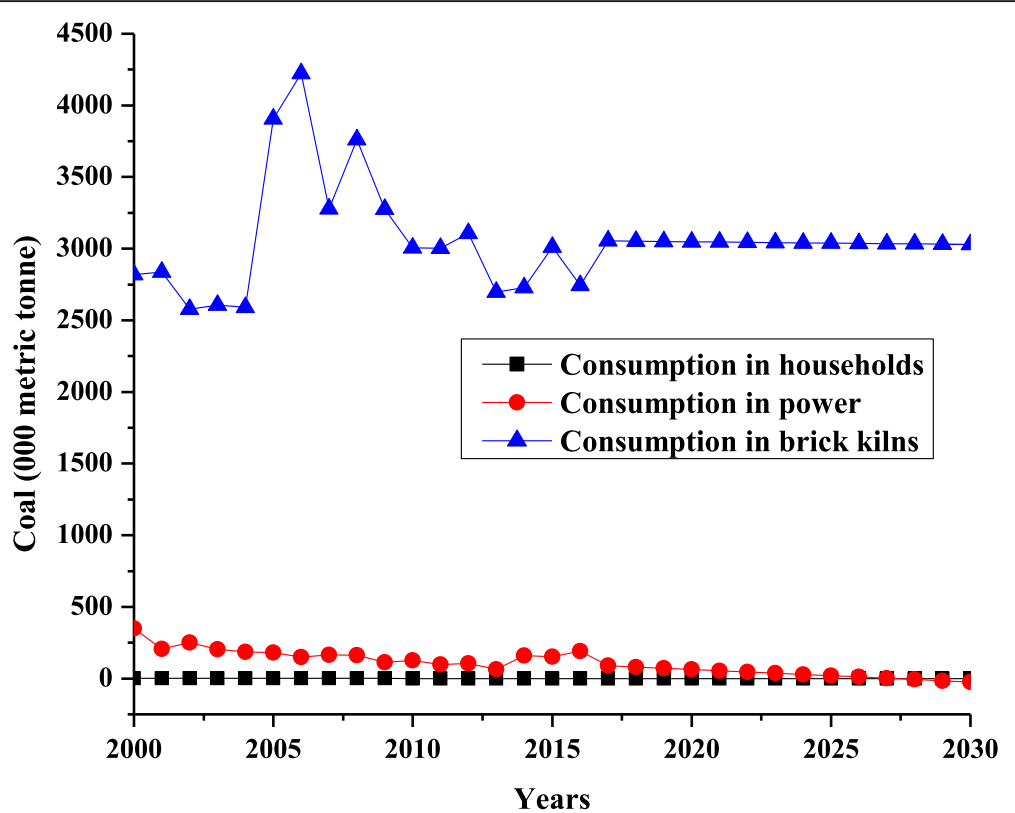

Fig. 4 Forecasted coal energy consumption in households, power and brick kilns from 2000 to 2030 (Authors' computations)

while oil is used for transportation, supplying about 93\% of the energy for transportation globally and for the EU [17]. The current state of the world's energy is facilitated by research and development with the aim to make the existing energy use more efficient. Coal energy consumption and its forecasting to 2030 for households; power and brick kilns are shown in Fig. 4.

\section{Conclusions and policy implications}

Pakistan's energy sector faces challenges with regard to insufficient production and supply. The purpose of this study was to demonstrate and forecast commercial energy consumption and supply from different sources including oil and petroleum, gas, electricity, and coal sources. The data were collected from the Economic Survey of Pakistan and HDIP.

In Pakistan, the development of appropriate policies for natural gas and oil production is not only necessary for improving and developing the energy sector, but also for economic development. The studies projections suggest guidelines which the Government of Pakistan may use to improve energy production from oil and other alternative sources. To increase Pakistan's current ranking in global coal production, it is necessary to implement greenhouse gas mitigation technologies and consider alternative energy sources. This study suggests and recommends that the energy sector needs further improvements and the initiation of new policies and funding schemes to fulfill the country's demands, including the consideration of solar electricity production.
Acknowledgements

The authors are grateful to the Research Center of Agricultural-RuralPeasants, Anhui University Hefei, China for its moral support. Moreover, the authors are also indebted to the reviewers for their positive suggestions that helped to improve the content of this study.

Funding

The paper was supported by the Research Centre of Agricultural-RuralPeasants, Anhui University Hefei, China.

Availability of data and materials

All data and material are available in this paper, so there is no other data to present.

Authors' contributions

AR conceived the study, collected the data, estimated the model, and drafted the manuscript. ZD read the article and made suggestions to the manuscript. All authors read and approved the final manuscript.

Ethics approval and consent to participate

It is declared that this paper does not involve any human participants, human data, or human tissue.

Consent for publication

This paper does not include any individual person's data in any form (including any individual details, images or videos).

\section{Competing interests}

The authors declare that they have no competing interests.

\section{Publisher's Note}

Springer Nature remains neutral with regard to jurisdictional claims in published maps and institutional affiliations.

Received: 29 March 2018 Accepted: 26 July 2018

Published online: 27 August 2018

References

1. Ali G, Nitivattananon V (2012) Exercising multidisciplinary approach to assess interrelationship between energy use, carbon emission and land use change in a metropolitan city of Pakistan. Renew Sust Energ Rev 16(1):775-786 https://doi.org/10.1016/j.rser.2011.09.003 
2. Pakistan Economic Survey (2011) Economic Advisor's Wing, Ministry of Finance. Government of Pakistan, Islamabad

3. Pakistan Economic Survey (2016) Economic Advisor's Wing, Ministry of Finance. Government of Pakistan, Islamabad

4. Perwez U, Sohail A, Hassan Syed F, Zia U (2015) The long-term forecast of Pakistan's electricity supply and demand: an application of long range energy alternatives planning. Energy 93:2423-2435 https://doi.org/10.1016/j. energy.2015.10.103

5. Song Q, Li J, Duan H, Yu D, Wang Z (2017) Towards to sustainable energyefficient city: a case study of Macau. Renew Sust Energ Rev 75:504-514 https://doi.org/10.1016/j.rser.2016.11.018

6. Mišík M, Nosko A (2017) The Eastring gas pipeline in the context of the central and eastern European gas supply challenge. Nature Energy 2(11):844 https://doi.org/10.1038/s41560-017-0019-6

7. Moral-Carcedo J, Vicens-Otero J (2005) Modelling the non-linear response of Spanish electricity demand to temperature variations. Energy Econ 27(3): 477-494 https://doi.org/10.1016/j.eneco.2005.01.003

8. Larson Bruce A, Bromley Daniel W (1990) Property rights, externalities, and resource degradation: locating the tragedy. J Dev Econ 33(2):235-262 https://doi.org/10.1016/0304-3878(90)90023-5

9. World Coal Association (2017). https://www.worldcoal.org/coal/uses-coal/ coalelectricity. Accessed on 10 Jan 2018

10. Pakistan Economic Survey (2010) Economic Advisor's Wing, Ministry of Finance. Government of Pakistan, Islamabad

11. Pakistan Energy Year Book (2012) Hydrocarbon Development Institute of Pakistan

12. Finley M (2013) BP statistical review of world energy. 2013 [2015-03]. http://www.bp.com

13. Economides MJ, Oligney RE (2000) Natural gas: the revolution is coming. In: SPE Annual Technical Conference and Exhibition. Society of Petroleum Engineers

14. Pakistan Energy Year Book (2009) Hydrocarbon Development Institute of Pakistan

15. Pakistan Energy Year Book (2013) Hydrocarbon Development Institute of Pakistan

16. Hower JC, Dai S, Eskenazy G (2016) Distribution of uranium and other radionuclides in coal and coal combustion products, with discussion of occurrences of combustion products in Kentucky power plants. Coal Combust Gasif Prod 8:44-53

17. International Energy Agency (2012) World energy outlook, 2012, p 690

\section{Submit your manuscript to a SpringerOpen ${ }^{\circ}$ journal and benefit from:}

- Convenient online submission

- Rigorous peer review

- Open access: articles freely available online

- High visibility within the field

- Retaining the copyright to your article

Submit your next manuscript at $\boldsymbol{\nabla}$ springeropen.com 